\title{
Creating Sacred Spaces: The Power of Rap Music on the Religioius Consciousness
}

\author{
Barbara B. Pemberton ${ }^{*}$
}

\begin{abstract}
Rap music is the sound and soul of the Hip Hop culture-a powerful social, musical, and political phenomenon of the late twentieth century. Born among the youth in the poor districts of New York, the genre has extensive roots: Puerto Rican, Latino, and Jamaican sounds, African tribal drumming, spoken poetry of the 1930s Harlem renaissance, blues music, spirituals, slam poetry, and oratory of the Civil Rights Movement. Developing right along-side this musical genre was the Five Percent Nation, a relatively unknown off-shoot of the Nation of Islam, that embraced the hip hop culture from its inception. God Hop, as some call the rap associated with the Five Percenters, became a natural conduit for the Nation's belief system. This paper will employ contemporary spatial theory to reveal how this unique symbiosis aided the construction of three categories of sacred space for the Five Percenters and how rap continues to serve as the glue that unites the group and also captures the imagination of new generations. More than just the public face of this new religious movement, rap provides physical gathering space, establishes ideological sacred space by articulating and contextuatizing sacred history, and continues to cast a vision for creation of a new, idealized just world order. Extensive new research traces the genre from its inception among marginalized, inner-city youth to the powerful prestigious rap artists of today, including Jay Z, Busta Rhymes, and the Wu Tang Clan. Both the Nation and Hip Hop have gone global, with Buddhist, Jewish, and Muslim rap artists also creating new cultural spaces while spreading a powerful, positive counter-culture message for social change-proving the adage: never underestimate the power of music on the religious consciousness.
\end{abstract}

\section{Introduction}

This paper will use contemporary spatial theory to gain a new perspective on how rap music, the sound of the Hip Hop culture, has been instrumental in building multiple layers of sacred space for the Five Percent Nation, or Nation of Gods and Earths (NGE). This controversial off-shoot of the Nation of Islam may be categorized as a new religious movement located in orally constructed sacred space, manifest wherever their beliefs are being affirmed. Just as the three great monotheistic traditions were first orally transmitted, the Nation has relied heavily on the faithful oral reproduction of its message, passing sacred truths from disciple to disciple through their "each one - teach one" methodology. Identity is tied to place, which does not necessarily require a physical, geographical location. Scholars in the social sciences, humanities, and philosophy agree space may be defined in other ways, such as social context, power structures, or by art and literary imagination. More than just the public face of a relatively unknown black

*Professor of World Religions, Ouachita Baptist University, USA. 
nationalist movement, rap music has provided physical gathering spaces, establishes ideological sacred space by articulating and contextualizing sacred history, and continues to cast a vision for a new, idealized, just world order. This cultural production creates "imagined" space: not "imaginary," but space that can be construed and/or experienced in no other way, yet space that still holds sway over group inclusion and exclusion, over behavior, and ultimately over eschatological hope. This study reinforces the adage: never underestimate the power of music to quicken the religious consciousness.

In this paper we will first take a brief look at contemporary spatial theory and use it to construct a rubric for analyzing the contribution rap music has made in constructing NGE sacred spaces. Three categories of space will emerge: physical or geographical, ideological or psychological, and visionary. To locate the Nation geographically it is important to first explore its history, including biographies of men most instrumental in the development of the ideas and stories that would become foundational to Five Percenter beliefs. This ideology will construct the next category of space, that of perception-the ideological or psychological. The Nation, and rap, offer a powerful counter-culture message of black supremacy primarily for poor, marginalized African American youth. As is the practice of many new religious movements, the Nation has incorporated into its stories geographical locations universally recognized as holy spaces, including Jerusalem and Mecca, (re)visioned for their own sacred history-Harlem is the New Mecca and New Jersey is the New Jerusalem. Last we will look at the ideals this movement has set out in their quest to establish a new, just world, a sacred space we will label visionary. Just as the Five Percent Nation has spread beyond the borders of the United States, Hip Hop culture, though often grossly misinterpreted and now declining to a degree on the American scene, is resurfacing elsewhere as a global agent for social critique and change.

\section{Spatial Theory and Sacred Space}

The concept of "space," and particularly "sacred space," has been studied by key thinkers from many disciplines, all employing their own field's particular vocabulary, often adding new terminology to explain a fresh perspective. Spatial theory in some ways parallels linguistic speech-act theory, recognizing words have the power to shape and transform environments. Recent sociological scholarship in spatiality offers an intriguing perspective: ordering space and its production into three categories. This paper will employ the categories used by New Testament scholar, Patrick Schreiner: physical or social space, ideological or 
mental space, and visionary ot imagined space. ${ }^{1}$ Within the field of religious studies all three categories may be considered "sacred space."

A religious movement may be located within each of the three categories of constructed space. "Physical space" is space that is empirically comprehended by adherents. Sacred history establishes the second category, "ideological space," or psychological space. It is the space of lived experiences filled with mental associations: some personal, some drawn from stories that inform the group's theology. It is the realm of perception-how the space is conceptualized: welcoming, or hostile, comfortable or oppressive. "Visionary space," or creative space, is the imagined world where the hopes and aspirations of the group are realized. In the religious context, visionary space may be construed as the idealized, utopian sacred cosmos. Physical space and ideological space may be contested, with visionary space offering a new reality, a place and identity powerfully communicated through story-telling. It is a place constantly under construction - real, yet not fully established. These relationally oriented categories are fluid by their very nature, and all three spaces may be experienced simultaneously.

Employing "space" as an analytical rubric, the Five Percent Nation may be situated within each of the three categories, with rap music instrumental in the cultural production of all three. NGE history does not only reveal physical space. The development of black racial consciousness and the personalities who drove it help explain the source of the sacred history which constructs their ideological space. Rap music, or "God Hop," by (or influenced by) Five Percenters, has served as a powerful change agent and tool for propagation, as well as a source for psychologically building up the people. The movement and music also offers visionary space, an ideal space of return to black dominance-back to the way things used to be-that is both/and, now real and experienced, yet still imagined and becoming through the black community. While living within the physical and ideological spaces, members have rejected injustice and corruption, choosing instead to embrace emancipatory identities as part of the Five Percent. Their visionary space is social subversion that crafts a new present reality and offers a glimpse of a new future social structure. This utopian ideal is the stuff of hearts and imagination and is therefore most powerfully communicated through cultural production-stories, art, and music.

But is the Five Percent Nation a new "religious" movement? Its own texts eschew the title, offering at first read an optimistic, Afro-humanism, intentionally rejecting any invisible god worshipped by the traditional revealed religions of Judaism, Christianity, and Islam, although it should be noted that some members of the Five Percent Nation adhere more closely to a form of traditional Islam than do others. According to their teachings, these western monotheisms project

1. Patrick Schreiner, The Body of Jesus: A Spatial Analysis of the Kingdom in Matthew (London: Bloomsbury, 2016), 19, 54. 
"whiteness" upon an image of a god revealed through white prophets, men who are also to be revered and followed. These now dominant religions are said to have been developed as intentional systems of oppression forced on black people through both secular and missionary colonizers and are antithetical to the truth and restoration of the black man to his original dominant status. That said, the Nation directly employs biblical references and Islamic terminology, as well as the ancient esotericism of the perennial philosophy, making new religious movement a legitimate classification.

\section{Physical Space}

Among many theological predecessors to the Five Percent Nation,the Moorish Science Temple appeared during the post-reconstructionist period of social upheaval as disenfranchised southern African Americans began to migrate north in search of jobs and a better way of life. New Jersey, "New-ark," or the New Jerusalem, was the site of the first Moorish Temple, or "The Canaanite Temple," established in 1913 by Noble Drew Ali. Shedding the social mores of the south, including traditional religious practices, these men and women were open to new ideas. One of many purveyors of unconventional spirituality was Noble Drew Ali, né Timothy Drew, born in 1886 in North Carolina. His biographical details, though vague, are said to include a Moroccan father, a Cherokee mother, a childhood spent with gypsies, and a teenage experience of Egypt where he was initiated into the ancient mysteries of the pyramid of Cheops. Ali drew his "Islamism," which he distinguished from the "slave oriented" "Arab-Islam," from his Circle7Koran [later, The Holy Koran of the Moorish Science Temple of America (1927)], full of black nationalism, Masonic symbolism, gnostic philosophy including Buddhist and Confucian references, and Islamic terminology. Most significantly, life with the Temple offered a new identity defined by place, complete with new Temple manufactured "passports:" blacks were not "African negroes" at all-but Moors, people of Moroccan descent, having roots going back to the Moabites, themselves descendants of the biblical Ruth. These ancient Moors controlled territory that included much of what is now known as the Americas, giving American blacks, or as they came to be called, the "Asiatic Blackman," pride of place, warranting full societal recognition and respect due original people-something unimaginable in the 1920s.

Temples were established throughout the South and mid-west, including Detroit and Baltimore. Ali opened his Chicago headquarters in 1928, where he taught a question-answer catechism, similar to the Masonic model, that clearly stated Allah is actually Man. Along with a fez, each member received an additional identity signifier-new surnames, "Bey" or "El"-the psychological importance of which cannot be overemphasized. Moral expectations and 
regulations also distinguished members of the community: no pork, tobacco, alcohol, shaving, or cosmetics. Whereas black nationalist Marcus Garvey and his Universal Negro Improvement Association (UNIA) urged racial separation and a return to Africa, Noble Drew Ali's Islamism offered a positive message focused on black pride, spiritual renewal, and a new political society in America. After Ali's still unexplained death, the congregation was eventually absorbed by other movements. Scholars argue over the extent of influence the Moorish Temple had on future movements. However, some concepts, especially the message of black empowerment, do continue in the theology of the later, more recognized group, the Nation of Islam (NOI). ${ }^{2}$

Another mysterious character figures prominently in the history of the Five Percent Nation: Master Fard Muhammad (one of over fifty aliases). His contested biographical details, like those of Noble Drew Ali, include an ambiguous ethnicity including having an Asiatic Blackman father and white Muslim mother. As the Depression stole both jobs and hope, Master Fard appeared in the ghettoes of Chicago, in the summer of 1930, as a door-to-door peddler of silk, African goods, and, as it would turn out, a renewed faith and identity for African Americans. His timely message, delivered amid enthralling stories of faraway Muslim lands, was well-received and spread to other cities. Some sources say he had within his new "Nation of Islam" over 8,000 followers in Detroit by 1933, including many adherents from the post-split Moorish Science Temple. ${ }^{3}$

W.D. Fard offered black supremacy delivered with Islamic terminology, featuring "scientific proof" that white people are devils created by the wayward young scientist Yacub. Fard asserted as well that white religion was intentionally developed as a tool to control blacks. Whites would rule for 6,000 years. Fard explained that at that time the original black people were not yet ready to rule; they were still trapped in the "wilderness" of North American and were following a "hocus-pocus" religion offering them only heavenly rewards in the "by and by." Fard had come to offer them hope in the here and now, and to proclaim the current grace period for the devil-one he prophesied would end with a return to black domination in 1934.

Fard reinforced his teachings by creating a unique language enviornmentexpecting followers to memorize his series of 154 orally transmitted secret lessons collected in his Teaching for the Lost Found Nation of Islam in a Mathematical Way. Written in a question-answer format, these lessons contained esoteric rituals for initiates only, doctrines of the godhood of the Black man, and an explanation of the black man's status as the progenitor of the entire human race. Just as his predecessor Ali disappeared mysteriously, so did Master Fard in 1934. But unlike Noble Drew Ali, Fard is said to have prepared a successor: Elijah Muhammad

2. Felicia M. Miyakawa, Five Percenter Rap: God Hop's Music, Message, and Black Muslim Mission (Bloomington, IN: Indiana University Press, 2005), 1, 9-12.

3. Ibid., 13. 
(born Robert Poole in Sanderville, Georgia, in 1897). Fard's congregation split, some members continuing to honor their Master as a prophet. But the community that chose to follow Elijah Muhammad deified Fard as the latest incarnation of Allah, and it is this group that became what is now known as the Nation of Islam. ${ }^{4}$

Drawing most of its membership from the streets, the NOI had few professional people in the early days. The one noteworthy exception was Dr. Abdul Salaam (Dr. Leo McCallum), Elijah Muhammad's dentist. ${ }^{5}$ During a skyped interview with the doctor, he gave participants in an academic institute on American Islam a detailed personal account of his experience in the NOI. Abdul grew up in Newark, New Jersey, in a staunchly Methodist Christian home. He said, "Sunday morning is the most segregated time in American." Friends began to come by with lessons, asking him questions about his identity he could not answer, even with all of his college degrees. They took him to the Temple where he met Malcolm X and learned that "Islam" meant freedom, justice, and equality. He soon was invited to go to Chicago to meet with "the Honorable Elijah Muhammad" himself. What he discovered was that, with all his education, he knew nothing about himself. Truths about man's African origins had been "covered up." He described Elijah Muhammad as a master at helping people be all they could be - and Elijah Muhammad called what he delivered Islam. The draw of this socio-religious movement was the relevance of the message: Do for yourself! When teaching, Elijah Muhammad used the Bible because it was what the people knew; he also knew enough from English translations of the Qur'an to incorporate relevant passages from it as well. And, since both his dad and granddad were preachers, he could deliver! Rather than focus on religious rituals, the NOI built an impressive infrastructure-a bank, the largest black businesses in the history of America, restaurants, schools-all to foster self-sufficiency and black empowerment.

Like so many of the black leaders of the day, Elijah Muhammad spent time in prison, a period about which little is known. Dr. Salaam claims Elijah Muhammad confided in him that he crafted the stories that held the Nation of Islam together while he was in prison. This revelation does not bother the now orthodox Sunni Dr. Salaam, because he thoroughly believes Allah used Elijah Muhammad to help the community. What does grieve Dr. Salaam is that Malcolm X gets so much more attention than Elijah Muhammad-the real visionary who deserves recognition for empowering the black community.

4. Ibid., 11-14.

5. Skyped interview with Dr. Abdul Salaam, Thursday evening, July 23, 2016, as part of the National Endowment for the Humanities (NEH) Summer Institute: American Muslims: History, Culture, and Politics, July 13-31, 2016, held at George Washington University, Washington, D.C. 
As the NOI grew, more temples were built, and more leaders were trained, including Malcolm X, who became the national spokesman in 1963 and minister of Temple \#7 in Harlem. The 1960s were tumultuous for the Nation, the tumult brought on in part by accusations of Elijah Muhammad's fathering several children through multiple affairs. In 1964 Malcolm X left the Nation after embracing Sunni Islam. Elijah Muhammad's own son Wallace, like Malcolm, also studied orthodox Islam, and would, following his father's death in 1975, take most of the NOI with him into what may be described as Sunni orthodoxy.

\section{Birth of the Five Percent Nation}

Another important defection from the NOI Temple \#7 was that of Clarence 13X, born Clarence Edward Smith in 1928 in Danville, Virginia, founder of the Five Percent Nation. Members of the NOI take an X, representing their unknown original family name, to replace their former names associated with white slave owners. The "13" indicates Clarence was the $13^{\text {th }}$ Clarence to join Temple \#7. Known to chafe under the strict morality rules of the Nation, and for his love gambling and alcohol, Clarence 13X also had theological differences with the Nation. Thinking through NOI doctrine, he came across several contradictions. In particular, he wrestled with the divinity of Fard - that Fard was Allah incarnate. He reasoned that, if the creator is the Blackman, then how could Fard, a white Arab at worst and a man of mixed parentage at best, be Allah? NOI doctrine also supposedly rejected any "mystery god," teaching instead that God is the Blackman. How could Fard be Allah if no longer present-and not black? Elijah Muhammad had proclaimed Fard's divinity in an article of 1934 entitled "A Warning to the Blackman of America:" "Let us rejoice and be exceedingly glad for our day of deliverance is come ... because our savior is in the midst of us and is doing great things. He will make everyone that hates him and disregards his call confess that he is God."6

Clarence's questioning led to his resignation, or by other accounts, expulsion in 1963, and his fiery speech led to the formation of a new movement, the Five Percenters. Ironically, his followers came to regard him as Allah in the flesh and gave him the title Father Allah.

The Five Percent Nation was born during the rough days of the 1960s - a time fraught with gang violence, race riots, and numerous radical organizations. It has its own checkered history of gang activity, violence, run-ins with the police,

6. Abdul Salaam, Is the Whiteman Still the Devil?: Myths vs Realities An Islamic Perspective (Victoria, BC, Canada: Friesen Press, 2013), 106-7. Some Five Percenters teach Fard's mixed racial heritage was purposeful; Fard would be welcomed by African Americans and his whiteness would allow him to navigate through cities unnoticed by white people. Pen Black, Gods, Earths and 85ers (San Bernardino, CA: 2007), 15. 
and even infiltration by the FBI. Clarence 13X did attract hardcore street youth, dropouts, and other outcasts and social misfits. Father Allah's first young disciples came to be called "The First Born." Each was expected to find ten other neophytes to teach personally. As the numbers grew, the emerging movement became known as "Allah's Five Percenters." Misinformation fostered constant apprehension on the part of society at large, for the new organization's members were young, trained in karate (through their earlier affiliation with the Fruit of Islam of the NOI), and associated in some way with the often misunderstood religion of Islam.

Clarence 13X was himself a notorious figure, hated by many groups: by the gangs because he was anti-gang, by drug dealers because he spoke out against drugs, by black power groups because he worked with city government officials, the NOI because he divulged the secret lessons, and the Sunni Muslims because he called himself Allah.The FBI kept a close eye on Clarence, even though he was a highly decorated Korean War veteran. After his arrest on marijuana possession and second-degree assault in March 1966, he was taken to the Matteawan State Hospital for the Criminally Insane where he was diagnosed with "paranoid schizophrenia with delusions of religious grandeur," but was released because he had been confined without trial.

In 1967, a time when Five Percenters were labeled nothing short of criminals, New York City mayor John V. Lindsay sent Barry Gottehrer, who was at the time in charge of the Urban Action Task Force, to establish a rapport with Father Allah. Together they organized city-wide activities and established the Allah's Street Academy at 2122 Seventh Avenue in Harlem - or Five Percenters' Mecca - which is still used as the movement's headquarters today. Other geographic locations were renamed by the Five Percent Nation: Brooklyn became Medina and Queens, the Desert.7 Linguists call this renaming of locations "semantic inversion." Scholar of African American Vernacular English Geneva Smitherman calls it an "act of linguistic empowerment."8

Five Percenters share many beliefs with the Nation of Islam and retain a few ties to al-Islam (Orthodoxy), often including important locations in their lyrics. "Mecca" (the birthplace of al-Islam) and "Medina" sometimes mean the cities of Saudi Arabia, but often refer to "Harlem" (the birthplace of the Five Percent Nation) and "Brooklyn" respectively, but the distinctions are not always obvious. Rakim raps in "The $18^{\text {th }}$ Letter:" "bring a praise from Mecca, make a phrase for the better."9

7. Other cities include: the Bronx is Pelan, Los Angeles and Louisiana are both Love Allah, Hew Haven is New Heaven, Atlanta is Allah's Garden, San Francisco is West Asia, C-God is Chicago. New Jersey has the distinction of being the New Jerusalem.

8. Geneva Smitherman, "The Chain Remains the Same: Communicative Practices in the Hip Hop Nation," Journal of Black Studies 28, no. 1 (September 1997): 17.

9. Ibid., 4. 
Clarence 13X was murdered on June 13, 1969, his assailant remains unidentified. He left no successor to the movement, trusting all his male followers would be leaders of themselves, their families, and the group that would, in 1976 declare itself a "Nation," a nation of black men and women, a Nation of Gods and Earths.

\section{Birth of God Hop}

In the poor districts of New York there emerged-right alongside the Five Percent Nation -"one of the most powerful cultural forces of the late twentieth century: rap music."10 What became the Hip-Hop culture took root among the youth in neighborhoods across the city and the Five Percenters embraced it from its inception. The genre actually had extensive roots: African tribal drumming (the "talking drum"), spoken poetry of the 1930s Harlem renaissance, blues music, spirituals, slam poetry artists, and even spokespeople of the Civil Rights Movement. Smitherman describes the rap artist as the "postmodern African griot, the verbally gifted storyteller and cultural historian in African society. As African America's "griot," the rapper must be lyrically/linguistically fluent; he or she is expected to testify, to speak the truth, to come wit it [sic] in no uncertain terms."11

Following the FBI's suppression of the radical black groups of the 1960s and the waning of gang wars, a new generation began to express itself on the streets through four elements that combined to create the Hip Hop phenomenon: DJing (deejaying), MCing (emceeing), B-Boying (break dancing), and writing (graffiti). Free outdoor block parties drew in huge crowds of young revelers; but these fetes were often illegal on two counts: no permits and the huge amplifiers were powered by the city grid. KRS-One raps about the early days in "South Bronx:"

Now way back in the days when hip-hop began

With Coke LaRock, Kool Herc and then Bam

B-Boys ran to the latest jam

But when it got shot up they went home and said "Damn

There's got to be a better way to hear our music every day

B-boys getting blown away but

coming outside anyway"

They tried again outside in Cedar Park

Power from a street light made the place dark

But yo, they didn't care, they turned it out

I know a few understand what I'm talking about

10. Miyakawa, Five Percenter Rap, 1.

11. Smitherman, "The Chain Remains the Same," 4. 
Hip-hop historians date the origins of the genre back to 1967, when the "Father of Hip Hop," DJ Kool Herc (Clive Campbell, said to be of Herculean stature), moved to New York, bringing with him memories of the rhythm and competitive nature of the musicians of his native Jamaica. As the story goes, in 1973 Clive and his sister Cindy decided to move the block party inside, by holding a dance in the rec room of their West Bronx apartment. ${ }^{12}$ The objective was simple: fun for the dancers; admission was $25 \pitchfork$ for ladies and $50 \pitchfork$ for gents. Since his dad was a record collector working for a local band, music and equipment were readily available. Kool Herc would later say, "This first hip-hop party would change the world." About the relationship with the Five Percenters he said, "a lot of Five Percenters ... used to come to my party ... you might call them "peace guards," and they used to hold me down [promise me protection]: "Yo Herc, don't worry about it." So we was havin' a good time."13 Black youth at that time were just trying to have fun, but they could hardly escape their ghetto situation and the need for cultural renewal. Hip hop culture and its rap music became a social, musical, and political mix. According to KRS-One: "Rap is something you do, hip-hop is something you live."14

The original DJ "Holy Trinity" were Kool Herc, Afrika Bambaataa (credited by some for having first used the term Hip Hop as a culture), and Grandmaster Flash, but by 1977 other artists were center stage. DJs, or turntablists, developed ways to use two turntables and a mixer to keep the music going. Meanwhile, a friend would also work to keep the party alive by encouraging the dancers, and so the "MC" was born. Early MCs took the role and ran with it-their entertainment style of moving the crowd developing into what became "rap."15

As Djs and MCs teamed up, the stiff competition made artists eager to develop new styles and hone their skills. At first, rap was only performed live, but in 1979 the first single was produced, "Rapper's Delight" by the Sugarhill Gang, and it went top-ten worldwide. In 1982 socially-conscious rap, exposing social ills like poverty and crime, became the rage. The mid-eighties are considered the golden age of hip hop featuring rap icons like LLCool J. By the late 80s studios were using drum machines, synthesizers and sampling (taking a section of music or other material-like a speech-and recording it for insertion in another composition). Early 90s producers added audio editing software, providing a way for new styles of alternative Hip Hop like jazz rap to develop. Most successful in the 90s were the hardcore rap of New York and the gangsta rap and G-Funk of Los Angeles, with the Five Percenter Wu-Tang Clan creating

12. In 2007 the rec room at 1520 Sedgwick was recognized as the official birthplace of Hip Hop.

13. Miyakawa, Five Percenter Rap, 21.

14. Ibid., 143.

15. Some MCs prefer the title "mic controller" to term "rapper" or the original "master of ceremonies." 
one of the first hardcore styles as they filled their lyrics with symbols and descriptions of gangster life.

Back when the party scene first moved from the streets indoors, it was the Five Percenters who stepped up and served as "peace guards," maintaining order and taking care of the new Hip Hop DJs. These events provided a physical gathering place for members of the Nation, a sacred space where they felt at home, as well as unique "classrooms" where their message was taught and affirmed. Members circled around the teacher/preacher DJ, a practice they called "building in the cipher (circle)," creating an inner "sacred circle." In 1987, Rakim Allah, became the first Rap MC to reveal his Five Percenter affiliation, and God Hop was born. Other MCs came out at the same time as members of the NOI, that religious movement having been reorganized under the leadership of Louis Farrakhan, who became instrumental in bridging the gap between the Five Percenters and the NOI. Bold rap artists continue to address the black youth audience as clearly stated by Chuck D, lead MC of Public Enemy: "I try to bring the youth into a level where they'll be interested to even begin to get into what the minister's speaking and the teachings of Elijah Muhammad, the reason for self-sufficiency in America, and the curiosity to learn more about themselves."16

\section{Ideological Space - Perception from Sacred History}

Five Percenter sacred history defines what may be called ideological space for this new religious movement, their stories providing a powerful counteridentity, particularly for poor, marginalized, "devil-indoctrinated" youth searching for respect. The NGE provides its community both a physical and mental location offering dignity, purpose, and opportunity, constructed by black prophets sent to rescue the "lost" tribe of the original people. Their creed, or in this case, "lessons," including Supreme Mathematics and the Supreme Alphabet (see below), masterfully carve out sacred space by receiving and enculturating members through mentorship and the spoken word. The Nation's faithfully memorized lessons are condensed and delivered in rapid repetition reminiscent of "spokenword" genre and rap music. Both rap and spoken-word focus on word flow and story-telling, but different rules apply. Rap focuses on rhythm, rhyme and musicality; poetry and spoken word do not have to rhyme. With rap you may take away the words and there is still a complex musical component-rap needs the beat. One member explains the benefits of the Nation's rhetorical technique:

16. Joseph D. Eure and James G. Spady, Nation Conscious Rap (New York: PC International Press, 1991), 359. 
"By utilizing Supreme Mathematics and Alphabets we elevate our intelligence, improve our memory and develop great oratorical skill."17

Not only is psychological, ideological space "built" by the lessons, but Gods and Earths are said to "build" their minds in dialogue as they "drop science," or share theological information.

Through the lessons Five Percenters learn who they "really are" and must "show and prove" their allegiance by verbalizing mathematical truths in a recognizable pattern in order to be welcomed into Nation space, showing and proving their true identity. Everyone, including the children, wake up to the cadence of the memorized lines. "A Five Percenter renews history at the start of every day, determining in advance how s/he will live out the day's reality with a blend of text and imagination." 18

God Hop rap artists attract young audiences with their music and image, then teach them, often subliminally, Five Percent theology. According to their sacred history, the Universe was originally triple blackness: only the black of space, water, and divinity. The human race began in pre-continental separation Asia, or what would become Africa. These original people were, like the original Universe, black, or "hue-mans," the high levels of melanin in their skin enhancing their mental capacities. From among the original people there arose a young, evil scientist named Yacob who, while exiled on the Island of Patmos, ${ }^{19}$ extracted a gene from a black person and thereby created white people, a physiologically inferior race, that would multiply and eventually plague future generations of the original people. This devilish white race would rule over the planet for 6,000 years, misleading and subjugating the original people until they had forgotten their true origins and identity.

The "lost-found" original peoples were moved, and became lost in the wilderness of North America where they have not thrived due to lack of opportunity, education, and self-awareness of their divinity. A prophet of their own, Master Fard, has now "found them" and shown them their original, natural way of Islam or peace; he came to reveal through mathematical percentages their true identities. According to the Lost-Found Lesson no. 2, questions 14 through 16 , eighty-five percent of the people are uncivilized, people who do not know who the Living God is and are hard to lead. Ten Percent are bloodsuckers, the "rich slave-makers of the poor" who teach the lie that God is an invisible "spook." This "Ten Percent" are responsible for stripping Africa of its resources and

17. Black, Gods, Earths and 85ers, 2. Five Percenters also are known for carrying around treasured photocopies of the lessons.

18. Michael Muhammad Knight, Why I Am a Five Percenter (New York: Jeremy P. Tarcher, 2011), 181.

19. In the Bible, the Apostle Paul was exiled to the Island of Patmos from Ephesus around the year $95 \mathrm{CE}$ and it is where he is said to have written the book of Revelation (Revelation 1:9-10). The Island is now part of Greece. 
damaging the black psyche; they also killed Jesus for preaching equality and justice. Islamic Arab invaders, part of the Ten Percent, enslaved Blacks before Europeans did and still treat them as second class. Moreover, both Islam and Christianity mislead their adherents to worship white people: a white Jesus and a white Muhammad. The Ten Percent continue to harm Blacks by encouraging homosexuality and birth control, both for population control. ${ }^{20}$

The Five Percent are the "poor righteous teachers," "Muslims and Muslim Sons," the civilized people who know the truth that God is the Black Man of Asia, and who teach Freedom, Justice, and Equality to all peoples. ${ }^{21}$ The task of the Five Percent is to "civilize the uncivilized," and to do so they practice what they preach by "staying in the pit of oppressions and hell (the streets) in order to raise people into the (mental) heaven of truth and Black justice."22

Hip Hop culture provides the platform and rap gives voice to the Five Percent as they create ideological space, for the faithful. The rap group $\mathrm{Wu}$-Tang Clan explains, ending "Wu-Revolution" with a lengthy spoken, not rapped for effect, section from the Lost-Found Lessons:

It was a hundred percent of us that came on the slave ships.

Eighty-five percent of our people was uncivilized, poison animal eaters;

they're slaves of the mental death and powers.

They don't know who the true living God is, nor their origins in the world.

So they worship what they know not, and they're easily led in the wrong direction,

far fewer men than right. Now you got the ten percent,

who are rich slave makers of the poor,

who teach the poor lies to make the people believe

that the Almighty true and living God is a spook in the sky,

and you can't see him with the physical eyes.

They're also known as blood suckers of the poor.

And then you got the five percent, who are the poor righteous teachers who do not believe in the teachings of the ten percent,

who is all wise and know the true and living God and teach that the true

and living God is the Supreme Being, Black man from Asia.

Otherwise known as civilized people,

also Muslims, and Muslim sons.

20. Black, Gods, Earths and 85ers, 46-47.

21. Yusef Nuruddin, "The Five Percenters: A Teenage Nation of Gods and Earths," in Muslim Communities in North America, ed. Yvonne Yazbeck Haddad and Jane Idleman Smith, 109-132 (Albany: NY, 1994), 115-116. Also Master Fard Muhammad, "The Supreme Wisdom Lessons." Retrieved from https://bit.ly/2EXNpLr.

22. Some of the NGE believe that people of any race may be part of the Five Percent. Black, Gods, Earths and 85ers, 6, 44. 
There are several sets of lessons to be mastered by Five Percenters in order to realize and live out their true identities as "scientists"-able to show and prove their knowledge and doctrinal understandings. Priority is given to the Supreme Mathematics and Supreme Alphabet with the intention of these principles guiding their daily lives by showing and proving factually what others would have to take on faith. If things appear to be going wrong, Lord Jamar raps in "Ain't No Mystery" by Brand Nubian: "Mathematically that just don't go."23

Supreme Mathematics and the Supreme Alphabet are used to "break down" words, or interpret them in Five Percenter parlance, sometimes with acronyms or by adding the numbers represented by each letter according to their place in the alphabet. Breaking down "Allah"-the Five Percenter deciphers Allah to mean "Arm, Leg, Leg, Arm, Head" which is interpreted to show and prove Allah is human. Islam is broken down via acronym to mean "I Self Lord Am Master." Breaking it down for the woman it reads: "I Self Love Allah Mathematics."24

Identifying themselves as Allah incarnate leads Five Percenters to live selfdirected lives, or as they would say, living within their own individual selfdefined orbit. There is no need for rules, or formal orthopraxy, for their form of Islam is not a religion but the original natural life of peace. NGE members may be distinguished from NOI members by their lack of dress code. Five Percenters break-down Sunni Muslim as "soon to be Muslim"-as one who has not yet gotten past believing in rules and archaic rituals. ${ }^{25}$

Because of the Supreme Mathematics, numbers are important, useful tools for rappers and are considered by some Five Percenters to be the very language of the Creator, having symbolic power on their own. Some artists use the Supreme Mathematics and break down numbers to express new meaning in various ways. For example, rather than saying the number sixteen, an artist may add the digits to come up with seven which represents God. Or the rapper may incorporate the meaning of each number in the verse. For example: the number one represents "knowledge" and six represents "equality." So when rapping "knowledge-equality," the Five Percenter may mean sixteen. For example, Brand Nubian raps in "Wake Up:" "I wrote this on the day of wisdom power," meaning the twenty-fifth. The flexibility of both systems, the Supreme Mathematics and the Supreme Alphabet, allows artists more latitude in their lyrics and personal exegesis of the Lessons provides ample material. Even variations in spelling can be creatively applied.

The symbolism of the Nation's flag serves to inform visually the identities for the Five Percent: the sun represents man (God), the moon, woman (Earth); the star, the child: The Nation of Gods and Earths. The rap group Poor Righteous Teachers identify themselves in "Strictly Ghetto:" "The sun, the seven, the moon,

23. Miyakawa, Five Percenter Rap, 25.

24. Black, Gods, Earths and 85ers, 4.

25. Nuruddin, "The Five Percenters," 129. 
and the star/Supremely shows and proves who we are." King Sun raps in "Universal Sun"26

The Sun is knowledge, knowledge is first Who's the man in your family for relevance Since you're learning man means intelligence The foundation of all that exists ...

The moon, secondary factor in life The sun and moon are like man and wife ... And the woman I'm made to own and to claim Reflects reality as highly supreme Secondary, but most necessary ... In conclusion, the moon is queen Earth is mother as far as I've seen Man and woman make up to the Zig-Zag Completes two fourths of the Universal Flag.

To flourish in their constructed ideological space-realizing their true identities-Five Percenters are to live with the pride and self-confidence that comes from the awareness that they are the descendants of the original people of the planet; that they are the Fathers and Mothers of civilization; that their Supreme Mathematics and Supreme Alphabet unlock all the mysteries of the universe; and that through their education they can and should be, self-sufficient people. The Nation also supports healthy living practices and moral living. Pork is banned, for, according to Clarence $13 \mathrm{X}$, the pig is "one third dog, one-third rat, and one-third cat," and who would eat that? ${ }^{27}$

Five Percent ideology upholds a strong patriarchal family order. "Earth" is Mother of Civilization, Queen of the Universe. She brings forth life, has her own lessons, and just as the planet has one sun, so the Earth has one Man. As King Sun raps, she is regarded as "secondary, but absolutely necessar." 28 In summary, members' lives should communicate that the Blackman is God, Allah; that the family unit is key; and respecting and educating their children is the future of the Nation. ${ }^{29}$

Each Five Percenter should also take seriously the mandate to "each one, teach one" according to their knowledge of the system, relying on elders to explain the deeper knowledge. Rap aides the memorization process and gives the lessons credibility. Farrakhan, speaking to rappers from both the NOI and the

26. Miyakawa, Five Percenter Rap, 28.

27. Barry Gottehrer, The Mayor's Man: One Man's Struggle to Save Our Cities (Garden City: NY: Doubleday, 1975), 97.

28. Black, Gods, Earths and 85ers, 41.

29. "What We Teach," Word 1, no. 2 (July 1987), 12. Quoted in Nuruddin, "The Five Percenters," 113. 
Five Percent Nation said that "one rap song is worth more than a thousand of my speeches."30

Gangsta rap icon Jay-Z delivers Five Percent teaching in "Heaven:"

Arm, leg, leg, arm, head - this is God body

Knowledge, wisdom, freedom, understanding, we just want our equality

Food, clothing, shelter/help a nigga find some peace

Happiness for a gangsta, ain't no love in these streets

Artist Lakim Shabazz uses the same lessons to stress his duty to each oneteach one:

Rhymes I make are designed to reach the youth,

I gotta teach, that's why I speak the truth

Some waste time dwelling on the past

It's time they know, that we're the lost tribe of Shabazz. ${ }^{31}$

\section{Visionary Space - A World that Can/Should Be}

Visionary space is the utopian ideal, a mental and cultural resurrection, as imagined by the movement. This vision has been set out as the Nation's goals entitled "What We Will Achieve." Hoped for are the following: first, National Consciousness, meaning achieving a universal awareness of the reality of who they are as a people and therefore living with that awareness under a new, Universal Government of Love, Peace, and Happiness for all. Second, Community Control, defined as the people themselves controlling the important aspects of their society, such as education, health care, economics, and media. As Gods and masters of their own destinies, of course they should be in control of everything that effects the community. When in control, the Nation will show and prove the greatness of their Divine Culture, which is Freedom. And third, Peace. Peace is defined as a lack of chaos or confusion. This means Order; Law and Order flow from the Supreme Mathematics, which is also the Science of

30. Quoted in Fahiym Ratcliffe, "Common Ground," Source, no. 144 (September 2001): 72.

31. The tribe of Shabazz is said to be the original tribe occupying the earth 60 trillion years ago before it split to create the moon. After surviving an attempt to wipe them out, the tribe discovered and settled on the "best part of the planet," the Nile Valley and Mecca,

Saudi Arabia. Elijah Muhammad [Elijah Poole], Message to the Blackman in America (Chicago: Muhammad Mosque of Islam No. 2, 1965), 31. 
Islam, or Peace. The ultimate goal is peace for all-"ourselves, our communities, in our nation, and in the world." 32

Five Percenters add to these aspirations "Twelve Jewels:" Knowledge, Wisdom, Understanding, Freedom, Justice, Equality, Food, Clothing, Shelter, Love, Peace, and Happiness. One Five Percenter has developed a long list of practical ways in which this visionary space may be realized: by taking an active role in the community, by entrepreneurship to become a producer rather than merely a consumer, by promoting charter schools that teach strong life skills and foster personal development, by pursuing a higher education to be of service to the community, by involvement in cultural production to enhance the Black image; by voting and seeking unity with the global black community. ${ }^{33}$

This message of peace and redemption has best been articulated and propagated by God Hop, expanding the Five Percenter Universe throughout the globe. Major figures include Rakim Allah, the Wu-Tang Clan, Poor Righteous Teachers, Brand Nubian, Queen Latifa (formerly a member), and Busta Rhymes. The memorized lessons provide an extensive repertoire from which artists may draw, employing their practiced verbal skills to captivate audiences and entice them to further inquiry, always with the intent to civilize the uncivilized. Nation terminology and methodology have resonated as relevant with contemporary culture and have made their way into common parlance, including phrases like "What's up G"-meaning "What's up God" (not gangsta)-and "Peace" (which broken down means "proper education always creates energy"). Not all references are equally clear, and some are slipped in merely for effect. However, Five Percenter MCs are upheld as authoritative teachers, and their work not only informs and unites their community, but also bonds them with other like-minded groups. ${ }^{34}$ In "We Dat Nice" Wise Intelligent explains:

\footnotetext{
We ain't just rappers, we changers of black situation

Teaching this Nation the way to conquer damnation

My occupation, to stimulate your elevation

To motivate and navigate the revelation.
}

Personal testimonies are key tools, such as in "B.I.B.L.E (Basic Instructions Before Leaving Earth)" by GZA which he begins with: "Knowledge this wisdom, this goes back to when I was twelve." GZA uses "knowledge" in the imperative mood, as in "listen up." Rappers "drop knowledge" through their lyrics. His story continues as he raps about his disenchantment with his Christian childhood upbringing, and his enlightenment to self-awareness at twelve. Other artists describe life experiences that confirm their street credibility; in the rap universe

32. Linked off the homepage at http://www.ibiblio.org/ngel.

33. Black, Gods, Earths and 85ers, 58-62.

34. Miyakawa, Five Percenter Rap, 42. 
authenticity challenges can be brutal. In "Ghetto We Love" Poor Righteous Teachers rap:

Rats in my front room, roaches in the back
Junkies in the alley running sale for the crack.
It was ill on the real, I be still buggin' off it
in the ways I was walking, so today I can talk.

Some rappers have used the language, but the message did not take for these "jive pretenders," as confessed by Grammy-winning rap star LL Cool J: "at its core there is strict religious doctrine, but we weren't following that. We were just using the Five-Percent label as a shield to do our dirty work-fighting and eventually robbing."35

On the other hand, the $\mathrm{Wu}$-Tang Clan, made up of nine emcees, take their teaching seriously, in spite of their apparent hedonistic life-style "ruling their own orbits." Wu-Tang MC Method Man teaches:

I fear for the 85 that don't got a clue

how could he know what the f--- he never knew?

God Cipher Divine come to show and come to prove

a mystery god, that's the work of Yacub

the holy ghost got you scared to death kid, boo! ${ }^{36}$

Rap artists are skilled at employing other techniques as rhetorical strategies, including syncopated rhythms, sampled sounds (including special effects and excerpts from famous speeches, sermons, or movies), flow, layering, punctuating ruptures, and even scratching. Hip hop scholar Tricia Rose finds within the use of these expressive techniques "a blueprint for social resistance and affirmation." 37 Ethnomusicologist and God Hop expert Felicia Miyakawa reminds the audience of rap's complex techniques' aesthetic value, which, added to the social value, "create a song's groove, and in so doing establish a participatory musical community within which the Five Percenter message can be effectively heard."38 Groove is the underlying rhythmic feel of music most often carried by the drums or base instruments. Black cultural production is also known for its use of repetition as a unifying device, employed not only in music, but also in dance and language. Ethnomusicologist, anthropologist, and linguist Steven Feld identifies repetition as the "glue holding together form, content, and groove," while others

35. LL Cool J, I Make My Own Rules. Quoted in Michael Muhammad Knight, The Five Percenters: Islam, Hip Hop and the Gods of New York (London: Oneworld, 2007), 50.

36. Knight, The Five Percenters, 183.

37. Tricia Rose, Black Noise: Rap Music and Black Culture in Contemporary America (Hanover, NH: Wesleyan University Press, 1994), 88.

38. Miyakawa, Five Percenter Rap, 73. 
argue variations are equally important, "Rap works rhetorically because it grooves. ${ }^{39}$ Rap artists and producers are all aware that the participation of the audience with the musicians is also important in order to plant seeds of doctrine. One should never underestimate the power of music on the religious consciousness, a concept producers of God Hop thoroughly comprehend and employ in order to "civilize the uncivilized" and bring the audience into the Nation. Even album art and organization serves a didactic purpose of introducing and/or reaffirming Five Percenter doctrine.

Envisioning the ideal, conscious rap developed as a sub-genre in the $80 \mathrm{~s}$ providing social commentary, promoting social protest, and exhorting African Americans to unity, self-sufficiency, and anti-materialism. In the face of black-onblack violence, Brand Nubian raps as follows in "I'm Black and I'm Proud:" "Do the knowledge, black, look at the way that we act/Smoking crack or each other with a gat/The only race of people who kill self like that." Still, ultimately Five Percenters "define their own orbit" in the Nation's Universe. ${ }^{40}$

The primary, life enhancing, self-empowering, nation building, community locating message, that the black man is God, is proclaimed by Brand Nubian in "Ain't No Mystery:"

See me and my people been lost for over 400 years

And done tried this mystery God and all we got was

Hard times, hunger and nakedness from the snake that hissed

Beaten and killed by the ones who said

Look to the sky for your piece of the pie

They didn't wanna tell you that God was yourself.

In "Butt Naked Booty Bless" Poor Righteous Teachers rap: "Praises are due to Allah, that's me." Rakim offers affirmation of this gnostic notion drawn from the Bible and the Qur'an in "Mystery:"

Which brings us back, to the mystic question, who is God?

Sixty-six trillion years since his face was shown

When the seventh angel appears, the mystery will be known

Check Revelations and Genesis, St. Luke and John

It even tells us we are gods in the Holy Qur'an

Wisdom, Strength, and Beauty, one of the meanings of God

G.O.D. you and me, Gomars Oz Dubar,

Knowledge, Wisdom, Understanding, Sun, Moon, Star

Man, Woman, and Child, and so is Allah.

39. Ibid., 98.

40. Ibid., 71. 
Doctrines define and establish the ideal Nation's boundaries, as explained in the chorus of "Inner City Boundaries:" "Once we have the knowledge of self as a people then we could be free/and no devil could ever enter the boundaries."

\section{Conclusion}

Hip Hop, or God Hop as some call the rap associated with the Five Percenters, developed right alongside the Five Percent Nation, and became a natural conduit for the Nation's belief system. It can be argued that rap aided the construction of three categories of space, particularly as it drew youth, and continues to serve as the glue that binds the imagination of new generations, providing a powerful voice to the already established verbal nature of the movement. Rap articulates their geographical location with vivid images of life in the hood - physical space. It then teaches the sacred history, (re)imagining the Black identity and providing a new self-image to take to the streets-ideological space. Then rap imagines for the Nation a world that can/should be, one of justice and equality for all-visionary space. All this "builds" within one well produced anthem by Brand Nubian, arguably the most obvious promoters of the Five Percent Nation: "Allah and Justice:"

Peace to the Gods, peace to the Earths,

Peace to the positive people of the Universe

Brand Nubian came to work it like this

Ya see, each, and every day

Each, and every way

We're gonna show and prove

Teach you the righteous way.

Peace, to Allah, and Justice, and justice, justice!

Peace, to Allah, and Juuhhhhstice! (repeat these two lines throughout the song)

The knowledge, is, the foundation

The wisdom is the way

The understanding shows you

That you are on your way

The culture, is I-God

The power is the truth

Equality only shows you

That you have planted your roots

God, came to teach us

Of, the righteous way

How, to build and be born 
On, this glorious day

The knowledge, of, the cipher

Is, to enlighten you

True that true that true that you

know

That God is right inside you

No longer a dominant force in the music industry, Hip Hop culture began its decline in the 1990s for many reasons, starting with the LA Rebellion of 1992 (Rodney King decision) which fostered less tolerance in the recording industry for rebellious language. In 1993 a new style surfaced, with thuggish elements from the drug culture and the popularity of "bling-bling." Also in 1993, the $1^{\text {st }}$ World Trade Center bombing brought a growing suspicion of anything Islamic. The rap "rallying issue" of South African apartheid ended in 1994, further hindering the movement, with a hard blow coming in 2001 with the attacks of 9/11. Religious studies scholar Michael Knight quips, "It's a known fact that white people ruin everything. If there was really a decline of hip-hop, it began when music executives realized that white kids were buying records."41

Though not as popular or mainstream in America as it was, Five Percenter/NOI influenced rap continues to have a positive influence on culture with no one accepting the use of extremist messaging, even as they consider much of their work a "jihad of words." However, artists do not hesitate to call out people in control, speaking truth to power. Knight writes, "What a religion stands for is often measured by what believers find themselves standing against, and the religion's demands that become emphasized are those that mark it as different from other traditions and communities." 42 And while the lyrics often sound provocative, rap artists encourage the uninitiated listener to take the words metaphorically. When they "drop a bomb," meaning knowledge bomb, to "sweep the Devil off the earth," they are "bringing evidence" that the devil of injustice ("white devil" is anyone unjust) needs to be eliminated.

Hip Hop has gone global, defining space in England and France, part of what has been called a "transglobal Islamic underground," where young Muslims are facing difficulty constructing cultural spaces for themselves. ${ }^{43}$ Watching the spread of the movement has been called "hiphopography." The Five Percent Nation is also global in reach, holding its annual "Show and Prove" gathering the

41. Knight, Why I Am a Five Percenter, 88. However, some Five Percenter literature insists the lessons are for "all human families." There is no much more to Hip Hop Culture than the four elements of break dancing, graffiti, DJing and MCing. A whole industry has grown up around it, including clothing lines and trendy food products.

42. Knight, Why I Am a Five Percenter, 74.

43. H. Samy Alim. Roc the Mic Right: The Language of Hip Hop Culture (New York: Routledge, 2006), 38. 
second week of June in Harlem. Rap's popularity in the Arab world has afforded the US State Department the opportunity to employ "Hip Hop Diplomacy," in its counter-terrorism efforts to defeat ISIS, offering a powerful, positive countermessage to Muslim youth. ${ }^{44}$

The Nation's worldview has also matured for the twenty-first century: anyone fighting for social justice may be considered a Five Percenter. First Born Bisme Allah writes: "Whenever there were masses of people who were being oppressed or used, abused and exploited by those who held power (10\%) the Five Percent (5\%) emerged to bring the masses out of their world of suffering." 45

Rap "Gods" performing around the world create venues for like-minded people to gather to enjoy their music and imbibe the message drawn from their now decades old sacred stories. The music transforms the audience into a selfaware, self-confident people ready to take on the problems that plague their societies. The visionary world of the Five Percent is one of peace and justice. The hope for its realization rests primarily with all our children.

From "Children R the Future" Big Daddy Kane raps:

On and on and on and on

Me say the beat don't stop until the break of dawn

Nor does the growth of our young world

Yes the children, be building, each boy and girl

Cause you are the cream of the planet earth

The new birth, now take that for what it's worth

And give the child room, to blossom and bloom

Livin large, it's your destiny to consume

To take flight and ignite to a brand new height

Cause that's your goalin life - am I right? (Yeah!)

44. Rashad Hussain, lecture "American Muslims and Foreign Policy" Thursday, July 30, 2016 at the National Endowment for the Humanities (NEH) Summer Institute: American Muslims: History, Culture, and Politics. Rap has been called a "weapon of mass culture." The rap of al-Islam, be it Sunni, Shiite or Sufi, tends to spin threads globally, whereas African American rap has Pan-African outreach. Recognizing music is haram (forbidden) to many orthodox Muslims, some al-Islam rap groups like Native Deen produce acceptable, nasheed, rap using synthesizer and drum, to bridge the generational and cultural divide. Women on the mic is also new.

45. The Five Percent Concepts: Allah World Manifest. Quoted in Knight, The Five Percenters, 196. 


\section{Bibliography}

Alim, H. Samy. Roc the Mic Right: The Language of Hip Hop Culture. New York: Routledge, 2006.

Black, Pen. Gods, Earths and 85ers. San Bernardino, CA, 2007.

Eure, Joseph D. and James G. Spady. Nation Conscious Rap. New York: PC International Press, 1991.

Gottehrer, Barry. The Mayor's Man: One Man's Struggle to Save Our Cities. Garden City: NY: Doubleday, 1975.

Knight, Michael Muhammad. The Five Percenters: Islam, Hip Hop and the Gods of New York. London: Oneworld, 2007

Knight, Michael Muhammad. Why I Am a Five Percenter. New York: Jeremy P. Tarcher, 2011.

Miyakawa, Felicia M. Five Percenter Rap: God Hop's Music, Message, and Black Muslim Mission. Bloomington, IN: Indiana University Press, 2005.

Muhammad, Elijah [Elijah Poole]. Message to the Blackman in America. Chicago: Muhammad Mosque of Islam No. 2, 1965.

Nuruddin, Yusef. "The Five Percenters: A Teenage Nation of Gods and Earths." In Muslim Communities in North America, edited by Yvonne Yazbeck Haddad and Jane Idleman Smith, 109-132. Albany: NY, 1994.

Ratcliffe, Fahiym. "Common Ground." Source, no. 144 (September 2001).

Rose, Tricia. Black Noise: Rap Music and Black Culture in Contemporary America. Hanover, NH: Wesleyan University Press, 1994.

Salaam, Abdul. Is the Whiteman Still the Devil?: Myths vs Realities An Islamic Perspective. Victoria, BC, Canada: Friesen Press, 2013.

Schreiner, Patrick. The Body of Jesus: A Spatial Analysis of the Kingdom in Matthew. London: Bloomsbury, 2016.

Smitherman, Geneva. "The Chain Remains the Same: Communicative Practices in the Hip Hop Nation." Journal of Black Studies 28, no. 1 (September 1997). 
